\title{
Business process reengineering in Ethiopian public organizations: the relationship between theory and practice
}

\author{
Tesfaye Debela $^{1}$
}

\begin{abstract}
Since 1994, the government of Ethiopia has embarked on reforming its civil service organizations with the objective of improving the public sector service delivery system. The government sponsored a lot of management training programs to enhance the capacities of civil service employees and to implement Result Based Performance Management System in all of its civil service organizations. Though this brought some improvements in the performance of some civil service organizations, the effort required was too much as compared to the benefits obtained. Since 2004, the government has also endorsed Business Process Reengineering (BPR) as a foundation for strengthening Result Based Performance Management System in the Civil Service. Scientific Management, Systems Theory and Operations Management are the theoretical and methodological foundations of BPR. For this reason, most corporations used BPR as transformation tool during the 1980s and 1990s. However, the characteristics of government organizations are different from corporate organizations. These distinguishing features constrain government organizations from emulating the BPR experiences of corporate ones. Hence, it is important to introduce a conceptual framework and a working model that facilitate the implementation of BPR in a particular civil service organization. Venktramen has developed the five stages of organizational transformation model. These stages are automation, horizontal integration, BPR, network redesign and organizational scope redefinition. The model helps to determine from which perspective to reengineer the processes of an organization - either to seek efficiency or to enhance capacity. Matching the statuses of civil service organizations in Ethiopia to this model indicates that BPR should be considered to seek evolutionary changes. In conclusion, considering the human resource and the technological capacities of Ethiopian civil service organizations, BPR can bring incremental benefit and evolutionary transformation instead of dramatic and radical change for foreseeable future to come.
\end{abstract}

Key words: BPR, Efficiency, Effectiveness, Organization Redesign, Management Information System (MIS), Information Technology (IT) , MCB, Civil Service Organizations

\footnotetext{
${ }^{1}$ is Faculty Staff in the Ethiopian Civil Service College.
} 


\section{Introduction}

\section{Background}

Few years after the downfall of the military government, the new Ethiopian government recognized the importance of improving the performance of service delivery and the creation of accountable and responsible civil service institutions that would support the development efforts in the country. To achieve these objectives, the government framed five pillars of the civil service reform program. They are the top management system, civil service ethics, expenditure management, service delivery and human resource management. The government established the Ministry of Capacity Building in the year 2001 in the name of the "Office for the Coordination of Capacity Building” (Proclamation No. 256/200: 1630-1632) to coordinate these pillars of reforms. The government redefined the roles and the responsibilities of the Ministry in the year 2005. The redefined responsibilities were identifying the capacity gaps in the country, formulating and coordinating the implementation of reform projects and programs, establishing the monitoring and evaluation system that ensures the effectiveness of reform programs, creating modern civil service system equipped with high human resource capacity, and paying attention to the expansion and utilization of Information and Communication Technology (ICT) in the country (Proclamation No. 471/2005: 3280).

Since its establishment, the Ministry has conducted quite a lot of management training programs such as customer service delivery, strategic planning and management and result based performance management with the aim of enhancing the human resource capacities of the civil service organizations. Though the progress made on quality is subject for further discussion and research, the Ministry has contributed a lot in spreading the concepts of management among government employees, and in bringing the different civil service agencies under the influence of change.

Since 2004, based on the general direction of the Ministry of Capacity Building, most federal civil service organizations have directed their efforts and resources towards implementing BPR. Though many claimed success, only few, for example, the 
Ministry of Trade and Industry, have slightly improved their efficiencies of service provisions (Tilaye, 1999). Therefore, the civil service organizations need to have workable model so that they can change their processes to improve the quantity and quality of their services/products.

\section{Objectives of the study and major questions}

This paper will address the following objectives:-

1 To introduce a model that facilitates the implementation of business process re-engineering (BPR) in the Ethiopian Civil Service Organizations.

2 To familiarise practitioners and trainers of the civil service reform with the theoretical foundations and development of the BPR.

Within the view of the above objectives, this paper discusses the theoretical background and the practice of BPR with the purpose of answering the following major questions.

1. What are the challenges and benefits of implementing BPR in the Ethiopian civil service?

2. Is it ethical to make an employee a subject of reengineering (Haag et al 1998: 113)?

3. What kind of change, incremental or radical, can Ethiopian civil service organizations bring after implementing BPR?

\section{Significance of the study:}

The study allows policy makers, firstly, to consider and revise the current approach of reengineering the processes of civil service organizations; and, secondly, to focus on strengthening the capacities of higher education institutions in research so that the institutions can support the effort of change in the country.

\section{The Research design and methodology}

The author used case studies mainly focusing on the Ministry of

Capacity Building where he was assigned as a consultant. The 
writer also purposely selected some civil service organizations, which were duly implementing BPR.

Data collection: - The primary data were collected using observation technique, participating in meetings, and interviewing officials and reengineering teams. The meetings were conducted at the ministerial and national levels between September 2006 and August 2007. The secondary data were drawn from theoretical reviews, BPR reports, the draft strategic plan of the Ministry and other relevant BPR documents.

Data analysis method: This research used mainly qualitative descriptions of situations and events happened in different ministries. The quantitative analysis was done using the time data captured by the procurement and finance process between April 2007 and July 2007. In addition, Venktraman model, as the theoretical framework, has been used to determine the status of BPR implementation for different processes in the Ministry and other civil service organizations.

\section{Structure of the Paper:}

This paper has five sections. This section sets the background, introduces the methods and objectives. The next section discusses the theories of management, the major concepts of BPR, the model for implementing BPR and the features that distinguish government organizations from corporate ones. The third section uses the five stages model of transformation discussed in the second section and evaluates how it worked in the Ministry of Capacity Bulling. The fourth section assesses the BPR experiences of other civil service organizations. The last section outlines the findings and suggested certain solutions to the problems that have arisen in civil service organizations currently implementing BPR.

\section{The conceptual framework}

\section{Revisiting the agents of organizational changes}

The history of management thought highlights that all management scholars have been mainly concerned with the issue of improving individual and organizational performances. Starting 
from the early 1990s, BPR has become one of the management tools to improve the performances of modern corporate organizations and government organizations. Discussing all the different concepts of management that directly or indirectly contributed to the concept of BPR is outside the scope of this paper. Hence the writer has used Table 1 to summarize few important theories, which are the foundations of today's BPR. 
Table 1: Revisiting the organizational changes

\begin{tabular}{|c|c|c|c|}
\hline $\begin{array}{c}\text { Schools of } \\
\text { management } \\
\text { thought }\end{array}$ & $\begin{array}{l}\text { Change agent and time of } \\
\text { change }\end{array}$ & Process and result & Contribution to BPR \\
\hline \multirow{3}{*}{$\begin{array}{l}\text { Scientific } \\
\text { Management } \\
\text { School }\end{array}$} & $\begin{array}{l}\text { Fredrick Taylor Between } \\
\text { late } 1880 \text { s and early } 19^{\text {th }} \\
\text { century }\end{array}$ & $\begin{array}{l}\text { measured and timed the movement of employees, } \\
\text { Improved efficiency two fold }\end{array}$ & $\begin{array}{l}\text { The importance of scientific selection, } \\
\text { education and development of } \\
\text { employees }\end{array}$ \\
\hline & $\begin{array}{l}\text { Frank B. and Lillian M. } \\
\text { Gilbert }\end{array}$ & $\begin{array}{l}\text { Motion study to find optimum economical motion; } \\
\text { and developed symbols for different movements in } \\
\text { work places (Burns, 2000, p. 39) }\end{array}$ & $\begin{array}{l}\text { The use of symbols for different } \\
\text { activities, and the use of workflow } \\
\text { charts to show sequences of activities } \\
\text { in the process }\end{array}$ \\
\hline & Henry Ford 1913 & $\begin{array}{l}\text { introduced assembly lines for his auto factory } \\
\text { (Wikipedia) }\end{array}$ & Process based manufacturing \\
\hline $\begin{array}{l}\text { Bureaucratic } \\
\text { School }\end{array}$ & $\begin{array}{l}\text { Max Weber (Late } 19^{\text {th }} \\
\text { century) }\end{array}$ & $\begin{array}{l}\text { Discussed the features of bureaucracy: hierarchy, } \\
\text { merit based promotion, specialization, impersonal } \\
\text { organizational climate, and rules and } \\
\text { procedures(Burns, 2000, p. 44-46) }\end{array}$ & $\begin{array}{l}\text { The negative connotation of } \\
\text { Bureaucracy helped practitioners to } \\
\text { focus on rules, procedures and } \\
\text { minimizing red-tapes }\end{array}$ \\
\hline $\begin{array}{l}\text { Human } \\
\text { relation and } \\
\text { behavioral } \\
\text { school }\end{array}$ & $\begin{array}{l}\text { Elton Mayo in 1920s and } \\
\text { 1930s, Abraham Maslow } \\
\text { in 1943, Douglas } \\
\text { McGregor in 1960s, Davis } \\
\text { and Canter, and Others }\end{array}$ & $\begin{array}{l}\text { o people are emotional beings that need } \\
\text { affection, love and belongingness rather than } \\
\text { rational beings that only aspire for economic } \\
\text { benefits. } \\
\text { o organizations are cooperative social systems } \\
\text { and not mechanically arranged entities (Burns, } \\
\text { 2000, pp. 59-72). }\end{array}$ & $\begin{array}{l}\text { The importance of empowering } \\
\text { employees to increase their interest in } \\
\text { their job. The method of job designs } \\
\text { such as job rotation, job enlargement } \\
\text { and job enrichment }\end{array}$ \\
\hline $\begin{array}{l}\text { Systems } \\
\text { theory }\end{array}$ & 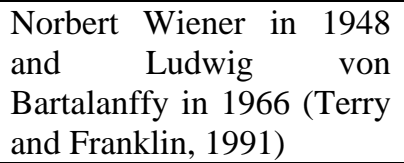 & $\begin{array}{l}\text { The concept that open systems interact with their } \\
\text { environment by taking input, transforming } \\
\text { (process) the inputs, and producing output }\end{array}$ & $\begin{array}{l}\text { Creating synergy of different } \\
\text { activities, } \\
\text { The breaking of processes into sub } \\
\text { process and activities }\end{array}$ \\
\hline
\end{tabular}




\begin{tabular}{|c|c|c|c|}
\hline $\begin{array}{l}\text { Contingency } \\
\text { theory (see } \\
\text { Burns, 2000, } \\
\text { p. 73). }\end{array}$ & $\begin{array}{l}\text { Tom Burns and George } \\
\text { Macpherson Stalker in } \\
\text { 1961, Paul Lawrence and } \\
\text { Jay Lorsch in 1967, and } \\
\text { Others. }\end{array}$ & $\begin{array}{l}\text { - Considered as situational approach and } \\
\text { challenges the concept of "universally } \\
\text { accepted principles of management". } \\
\text { - Tries to integrate theory with practice in a } \\
\text { systems framework. }\end{array}$ & $\begin{array}{l}\text { The type of environment determines } \\
\text { the type of structure of organization }\end{array}$ \\
\hline $\begin{array}{l}\text { Total quality } \\
\text { management }\end{array}$ & $\begin{array}{l}\text { W. Edwards Deming and } \\
\text { Joseph Duran (Monks, } \\
\text { 1987, p. 581) }\end{array}$ & $\begin{array}{l}\text { Improving quality or producing "zero defect } \\
\text { products through teamwork. The Japanese used } \\
\text { TQM to become dominant in the international } \\
\text { market. }\end{array}$ & $\begin{array}{l}\text { The importance of team work called } \\
\text { quality circles in determining the } \\
\text { quality of a product, and the use of } \\
\text { statistical quality control. }\end{array}$ \\
\hline $\begin{array}{l}\text { Value Chain } \\
\text { Activities }\end{array}$ & Michael Porter & $\begin{array}{l}\text { Business organizations perform five sequentially } \\
\text { arranged core activities: Inbound Logistics, } \\
\text { Manufacturing, Outbound Logistics, Marketing } \\
\text { and Sales, and After Sales Service. }\end{array}$ & $\begin{array}{l}\text { Segregation of activities into value } \\
\text { adding and none value adding. }\end{array}$ \\
\hline $\begin{array}{l}\text { Organization } \\
\text { and method } \\
\text { Study }\end{array}$ & $\begin{array}{l}\begin{array}{l}\text { Practiced by many } \\
\text { corporations }\end{array} \text { and } \\
\text { government organizations } \\
\text { in the 1970s and 1980s }\end{array}$ & $\begin{array}{l}\text { studying workflows, work procedures, forms } \\
\text { design, office layout, and types of communication } \\
\text { in organization, }\end{array}$ & $\begin{array}{l}\text { Except focusing on a single process at } \\
\text { a time, O\&M is the foundation of } \\
\text { BPR. }\end{array}$ \\
\hline
\end{tabular}

Source: Summarized by the author from different sources 


\section{System's performance: efficiency, effectiveness and flexibility}

Many training manuals on result based performance management system consider four parameters - cost, time, quantity and quality to measure the results of organizations. However, time and cost measure the process and the inputs respectively; whereas quantity and quality measure both inputs and outputs. Besides, these parameters hardly measure the performances of organizations. As a result, the Ethiopian civil service organizations have succumbed once again into measuring activities and inputs instead of measuring results. Hence, understanding the concepts of efficiency and effectiveness is vital because they are the cornerstones for measuring the performances of an organization at three levels: individual, team and organizational levels.

Efficiency: is defined as the degree of outputs produced per given set of inputs. Input consists of raw material, labor, technology, capital, etc. Efficiency of a system depends on system's internal factors such as coordination of activities, motivation of employees, the way jobs are designed and the technology applied.

Efficiency can be operational efficiency and managerial efficiency. Operational efficiency measures either the ratio of physical output to physical input for manufacturing organizations or the number of customers served per given time for service providing organizations. In contrast, managerial efficiency measures the speed that a manager accesses information and responds to a problem/opportunity in the form of instruction, report, decision, or answer. This speed depends on the quality of stored information (organizational memory), the information system used to access internal/external information, the knowledge and experience of the decision maker to analyze the information, the complexity of the subject at hand, etc.

Effectiveness: measures the ability of a system to handle the complexities in its environment. In order to survive, any system needs to cope up with changes in, or to induce changes to its environment. The business environment of a system consists of a lot of other business systems and entities with which the system in question interacts. The complex external situation compels the 
system to balance its internal capacity with the varieties of the environment it handles (Ashby cited in Davies and Demb, 1979). If a system handles environmental varieties higher than its internal capacity, the system overstretches itself beyond its available resources and energy that leads to the deterioration of performance. If a system handles environmental varieties less than its internal capacity, the system under performs much below the expectation. Tersely, effectiveness measures the outcome and impact of a strategy

Flexibility: In measuring the effectiveness of a system, we have to consider not only the varieties but also the state of the business environment. The continuous change in the state of the business environment compels the system to change its behavior to adapt to different situations. Hence, flexibility is the speed at which the system changes its behavior/action in relation to the changes in its business environment.

\section{The business process reengineering (BPR)}

The brief review of changes discussed so far helps to link the principles of BPR to the principles of scientific management school, total quality management and systems theory. As mentioned in the introduction part, the Ethiopian government has taken BPR as a panacea for the problems of inefficiency in the performance of the civil service organizations. Therefore, it is important to discuss the concept of BPR before we discuss its applicability to civil organizations in Ethiopia.

Some corporations began to practice BPR in the mid 1980s before Hammer and Champy developed the theoretical framework during the early 1990s. Many management consultants/scholars, during the 1970s and 1980s, had used operation management techniques to improve the efficiencies of the then business organizations by answering fundamental questions like "why do we do what we do? And why do we do it the way we do it?" For example, Monks (1987: 178) defined flow process charts as a tool to "facilitate analysis by asking why each activity is done, and whether it can be improved by eliminating a task, combining tasks, changing the sequences of tasks or simplifying tasks". 
These are the same fundamental questions that need to be investigated in today's practice of BPR.

Hammer and Champy (1993: 32) defined BPR as "the fundamental rethinking and radical design of business processes to achieve dramatic improvement in critical measures of performance such as cost, quality service and speed." According to Laudon and Laudon (1998: 407), business reengineering is analyzing, simplifying and redesigning the business process to radically improve the cost and the quality of a product or service.

The previously discussed literature purports that the theoretical and the methodological foundations of BPR are scientific management, systems analysis and design, operations management, computer technology and others. BPR agrees with scientific management school in two aspects. The first is the "rational thinking" that money is the only motivator of employees. For example, according to Hammer and Stanton (1995: 166), the "way to people's hearts and minds is not through their ears but through their wallets" (emphasis mine). The second is the mechanistic thought that "reengineering is deterministic, not probabilistic." (Hammer and Champy, 1993: 14) excludes the environmental and human factors from the equation of organization design. However, for our further discussion, the fundamental issue to be noted is that system's theory is the foundation of BPR, because the characteristics of systems- input, processing and outputs- are essential at the time of reengineering a business process.

In general, some of the major principles of BPR, as discussed by Hammer and Champy (1993), are integrating horizontal activities end-to-end, organizing the process around the outcome, capturing information at the source, and putting the decision point where the work is performed. These principles can be interpreted into four major areas of structuring organizations. Those are automation, authorizing the employee, bringing the employee to the front line and provision of services to the maximum satisfaction of customers. Hence, it is essential to elaborate on two fundamental concepts- information control and decision-making power- in the management of organizations. 


\section{Is BPR MIS solution or organization redesign solution?}

MIS solution and organization re-design solution are two options that affect the design of an organization. These options deal with the problem of narrowing the distance between the location of information and the location of decision-making right (Nault, 1998). In a bureaucratic organization, information is found at the operational level of the organization whereas decision-making right is found at the top level of the organization. When information vertically passes from the bottom to the top level of the organization, a tall organizational structure increases information asymmetry where as a flat organizational structure minimizes information asymmetry.

Favoring the MIS solution implies moving the information to the location where decision making right is found. The more the top management wants to control the operational activities of an organization, the more it uses the MIS solution to minimize its information asymmetry. Hence, the top management uses the strategy of MIS solution to eliminate the middle level positions and to reduce the hierarchies of the organization. Consequently, the more the MIS solution is sought the more flat the organization structure becomes. This compels the top management to consider organization redesign solution; delegating more decision making power so that operational managers can make local decision using local information. Favoring the organization redesign solution implies moving the decision making right to the operational level where the information is located. Hence, the choice between the MIS solution and the organization redesign solution rests on how to allocate information and decision-making right together.

In general, BPR can deal with finding the optimal point where the top management maximizes control through the application of ICT and where the employee maximizes empowerment through organization redesign solution. In short, the optimal mix of the MIS solution and the organization redesign solution creates a new process - as what Hammer and Champy (1993) called the "hybrid" of centralized and decentralized operations 


\section{Venktraman's model for reengineering a business process}

Venktraman discussed five levels of the application of ICT in organization design whereas Laudon discussed four stages of organizational transformation (Venktraman 1994, Laudon and Laudon, 1996). In the following part, we discuss the five stages of Venktraman's model that help to determine for what objective and result should an organization implement BPR.

1) Automation (local exploitation): Automation refers to the use of ICT to improve the efficiency of employees in offices. For example, consider two interrelated work units- inventory control system in warehouse unit and accounts payable system in accounting unit. Each operational manager can be highly interested in automation to improve the operational efficiency of his respective unit. This is what Venkatraman (1994) called "localised exploitation" of ICT. Tersely, automation is the use of ICT to improve the performance of a particular functional process.

2) Horizontal integration: After automating the functional units, the elementary activities are rearranged again to form higherlevel work process. Venktraman (1994) discussed two major higher-level integration activities in an organization. The first is the technical linkages and interfaces of different systems and applications, which are dealt through ICT. The second is the business process interdependence that redefines organizational roles and responsibilities across functional lines. In other words, it is the process of streamlining of the standard operational procedures and eliminating the bottlenecks so that automation can make operating procedures more efficient (Laudon and Laudon, 1998). This leads to eliminating functional boundaries through integrating horizontal activities.

For example, performing the sales, store and accounting functions would have required assigning a seller to write invoices, a cashier to receive cash, a store man to record the shipment and an accounting clerk to post the transactions in to their accounts. However, computerizing these functional units allow the system to generate receipt to the customer, to post the sales transactions 
to their proper accounts when sales transaction occurs; and to prepare financial statements whenever needed. This leads to defragmenting horizontally related tasks and to be done by an employee who has the knowledge of sales, store keeping and accounting. This is why modern organizations prefer generalists to specialists, particularly for operational level administrative works.

Figure 1: Levels of Transformations

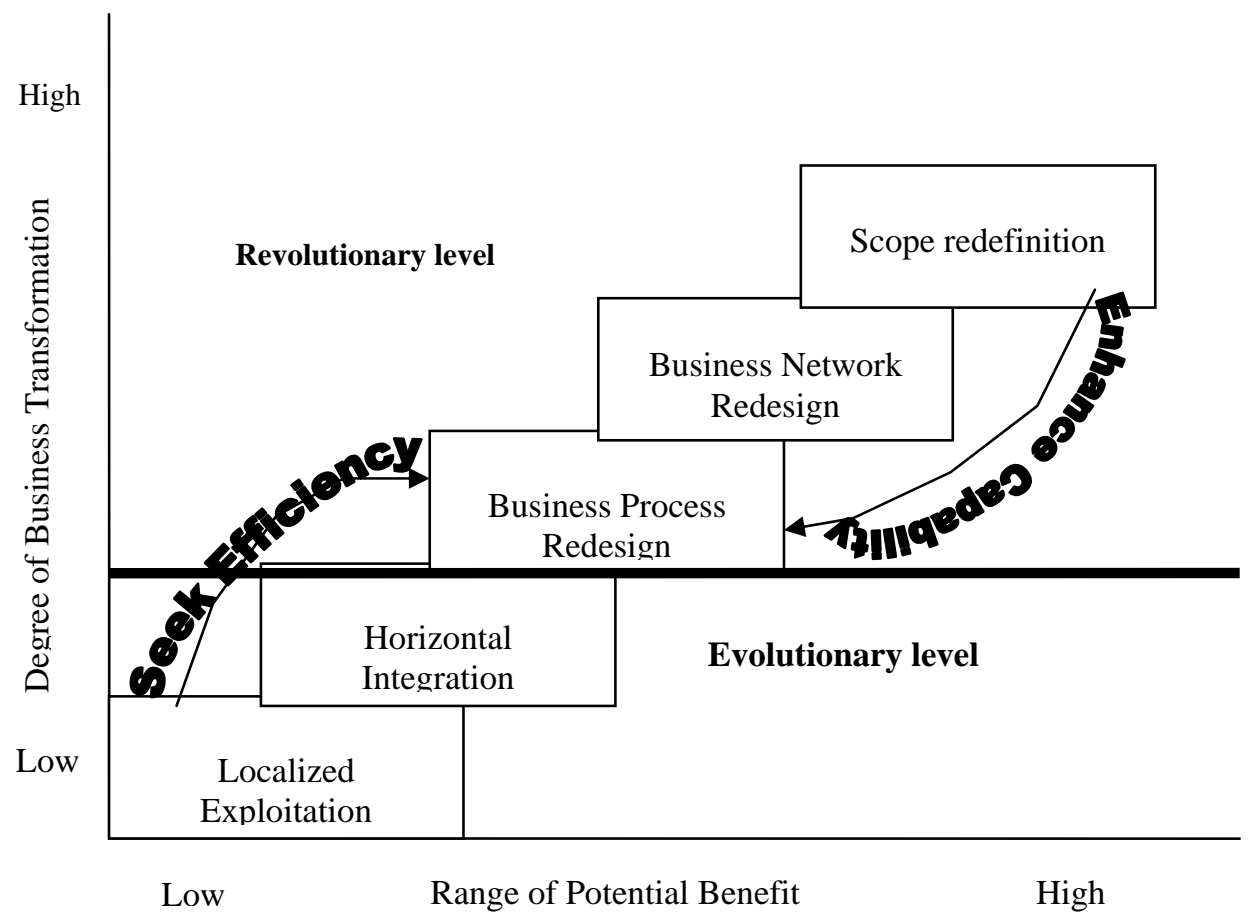

Source: Adopted from Venktraman, Sloan Management Review

3) Business process redesign (reengineering): BPR does not imply the application of ICT on the existing business process; but implies a complete renovation of the business process before the application of ICT to avoid the automation of inefficient activities of the process. The major questions of BPR focus on the rationality of the existing business process, the significant changes taking place in the competitive environment, and the cost of continuing with the existing process (Venktraman, 1994). 
4) Business network redesign: This refers to the application of ICT to enhance the interface and to create strategic alliance and cooperation between the participants in the business network. Business network redesign ranges from linking the organization to its customers and suppliers through EDI (Electronic Data Interchange) to creating opportunities for unstructured tasks, for strategic alliance and for knowledge control (Venktraman, 1994). The network technology has eliminated the walls and shortened the distances existing between organizations and has created the opportunity for cooperation and partnership. For example, the technology of business enterprise networking has enabled bank customers to obtain bank services anywhere and anytime they want.

5) Redefining the scope of the organization: The major question here is what role ICT plays in influencing the business scope and the logic of business relationship (Vanktraman, 1994: 83). Scope redefinition involves the rethinking of the mission of the organization, the business it is in, and the network it has with strategic partners and allies so as to bring a paradigm shift in the business activity.

Figure 1 helps to deduce theories and hypothesis for applying BPR in an organization. If an organization is found either at automation or at horizontal integration level of using Information Technology, that organization is doing BPR to seek efficiency. Hence, the organization is found at the evolutionary level of transformation. If an organization is found at the strategic level i.e. at the stage of network redesign or redefinition of scope, the organization undertakes BPR to enhance its capability and it is found at the revolutionary level of transformation.

Considering the model in the context of Ethiopia, the main question is: Does BPR bring evolutionary transformation or revolutionary transformation in the reorganization of the Ethiopian civil service. Before discussing this point, let us recapitulate some general characteristics of government organizations. 


\section{Features of government organizations}

The practice of applying the BPR experiences of American Corporations to Ethiopian Civil Service Organizations has blurred the differences in characteristics between profit making corporations and civil service organizations. Both government organization and business organizations have different motives when implementing BPR. The three Cs - customers, change, and competition - are the driving forces in reengineering a corporation (Hammer and Stanton, 1995: 12). Behind all these "C"s, there are the underlying objectives of profit and survival. In contrast, the motives of a government to undertake BPR are to provide efficient and quality services to the citizens, to minimize budget deficits, to make the country competitive in attracting foreign investments, and others.

According to Borins (2000), USA and Canada were the pioneers to borrow the techniques of BPR from the private companies and to apply it to their civil service organizations. As to USA, a team of advisors led by Al Gore, the Vice President of USA between 1992 and 2000, produced a report, titled 'Creating a Government that Works Better and Costs Less', in September 1993 (Gore cited in Borins 2000). Following this report, the civil service organizations went through continuous reforms between 1993 and1996. One of the techniques used during that time was reengineering (Borins, 2000). Hence, the Clinton Administration saved costs, reduced staff, improved service, and increased the use of Internet in the federal government offices. As to the structural changes of the civil service, refer to the discussion made by Tesfaye (2009).

Traditionally, any state is responsible for playing the role of regulatory functions, maintaining security, law and order in the country, and protecting the country from any external threat (Stahl, 1962) In addition to these, modern states are responsible to provide social services to their citizens, and to uphold the principles of good governance: transparency, fairness, equity, efficiency, effectiveness, accountability, participation, responsiveness, etc. in their political administration. Any government discharges these responsibilities using different agencies and manages its agencies through policies, rules and 
regulations. Hence, it is important to highlight some of the major characteristics that distinguish government agencies from profit/private organizations (Leenders et al 1989: 513-519) so as government agencies can consider the situation they are in when they apply BPR.

Service provisions: Government services are not governed by market prices rather they are governed by legal provision, rules, procedures and regulations. Hence, the monopolistic control of government services makes the philosophy of "customer is the king” somewhat ambiguous particularly in developing countries.

Sources of authority: - The authority of any civil service organization emanates from the parliament and the authority is established by law and regulation. Thus, a manager of any government organization has to observe the laws and to recognize his accountability to the legislative body and ultimately to voters who elect this body.

Sources of finance (budgets): A government finances the operation of its agencies by collecting taxes from the public, by obtaining aid from donors or by borrowing fund from lenders. It is the legislative body that finally approves the budget of an agency. As the agent of the people, the government establishes systems and rules to control how a government organization can spend the budget.

External pressure: - In a democratic society, managers of public organizations are subject to public hearings and open criticisms for their actions. For this reason, most managers in the public sector do not like to take risks by thinking outside the bounds of the existing rules, procedures and regulations, even if they know the best method that dramatically improves the performance of the civil service organization they manage.

Creating employment opportunities: - One of the responsibilities of a government is to create conducive environment for investment and economic growth with the objective of creating employment opportunity for its citizens. BPR is not only the source of job insecurity for employees but also increases the worry of the politician in balancing the efficiency obtained from implementing BPR and the disappointing effects of BPR on 
employment.

Political influence: Organizational politics is about power relationship and control of resources in organizations. No organization is free of organizational politics. Theoretically civil service employees are expected to remain neutral and they serve the nation irrespective of the political party in power. However, civil service organizations in developing countries usually fall under the influence of the politicians because they are the instruments to impose law and order and to implement government policies and strategies. For example, the former military government passed a lot of instructions, rules and regulations to tighten the bureaucracy by way of controlling the behavior of the civil service institutions and forcing them to adhere to its ideology.

Figure 2: The conceptual framework of BPR for the Ethiopian civil service organizations

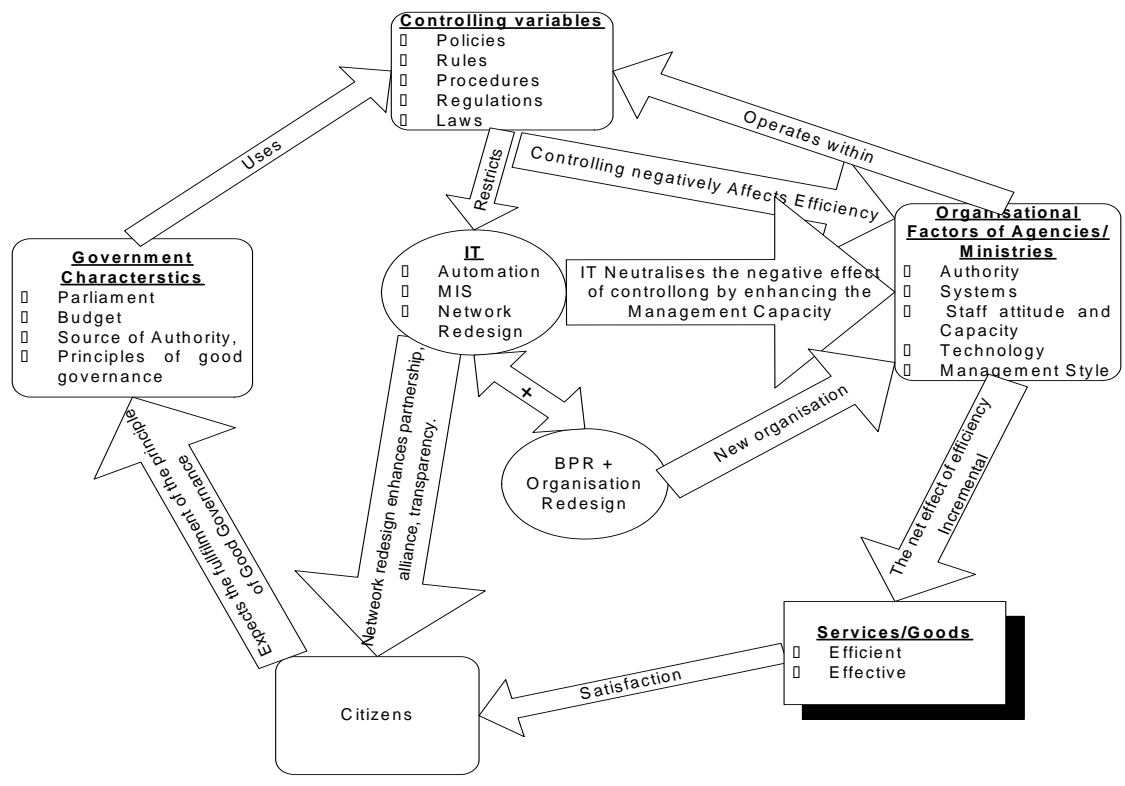

\section{Source: own conceptualization}

Figure 2 summarizes all what we have discussed so far on BPR and the characteristics of civil service organizations. On one the hand, government organizations operate within the control 
variables of the government that negatively affects the flexibility, efficiency and effectiveness of delivering public services. On the other hand, the objectives of BPR are to improve the efficiency of government organizations. Therefore, IT enhances the managerial capacity and consequently the efficiency of the civil service organization by automating the steps and neutralizing the negative effects of the controlling variables.

\section{BPR in the Ministry of Capacity Building}

\section{Attacking the "inefficient bureaucracy"}

The Federal Civil Service Agency, the former Central Personnel Agency, was established around the early 1960s to administer the staffing of the civil service. This bureaucratic system was too archaic and non-responsive to the technological and social changes that took place for decades after its establishment. Therefore, reengineering the civil service processes (BPR) may be the right solution to eliminate the red tapes and the redundant activities that have stifled the operation of the whole civil service

The Ministry of Capacity Building (MCB) currently oversees the activities of the Federal Civil Service Agency, the Ethiopian Management Institute and the Ethiopian Civil Service College. In addition, the Ministry manages many programs such as the Civil Service Reform Program, District Level Decentralization Program, Information and Communication Technology Development Agency, Justice Reform Programs, and others. This Ministry is the leading institution to implement the civil service reform programs throughout the country with the objective of creating modern civil service staffed with high human resource capacity. Hence, it is vital to assess how the Ministry is changing itself before it enforces changes on other ministries and government agencies.

The MCB started reengineering its processes in October 2004. However, the Ministry aborted the first study, presuming the process designs were functional. The Ministry formed new reengineering teams and they were trained on BPR. After the Reengineering teams conducted successive meetings in February 
2006, the teams identified five core processes and six support processes. After designing for six months, the teams reported the completion of redesigning the identified processes (

1998 ) around the end of August 2006.

During the first weeks of September 2006, the reengineering teams presented the redesigned processes to the steering committee of the Ministry. At the end of the meeting, the Ministry formed an organizing committee and gave an official blessing to the committee to design a flat structure for the Ministry based on the new reengineered business processes. The steering committee planned to finish organizing between September 2006 and the end of December 2006 and to commence result based performance management system in January 2007. In December 2006, the organizing committee reported the completion of its assignment. Besides, the steering committee scheduled the month of January to test the new organization structure. However, organizing was not as such simple. The document submitted pointed out that the team needed more capacity to design and bring realistic organizational structure.

After the approval of the "To Be" (newly redesigned) processes in September 2006, the reengineering teams took more than sixteen months to refine and rectify the reengineered processes. Organizing activity was introduced again in December 2007. But the management was not confident with the designed processes and recommended the postponement of the implementation of the balanced score card until the BPR would be rectified and operational.

\section{System characteristics: interface, inputs, outputs and impacts}

The discussions in a lot of meetings indicated that there was problem of clarifying the conceptual relationship between input, processes, output, outcome and impact of a specific process. The output is the immediate result of the process. Outcome is about the degree of acceptance of the output by the customer. Impact measures the change brought to the user or other external entities as a result of the intervention. Reengineering Teams of the Civil Service Reform Program, District Level Decentralization Program 
and the Planning and Programming Directorate took longer time than anticipated to identify mainly their customers and other stakeholders- such as partners, regulators and suppliers of their processes.

\section{Application of ICT: automation (database), horizontal integration, the MIS solution and network design}

Automation: Since January 2007, Automation has been one of the main issues in many of the meetings of the steering committee (refer to section 2 for the explanation of automation). However, no process of the Ministry was able to have computerized database to manage its operations. Employees were asked whether they had taken trainings on software identified for their processes. Table 1 shows that almost $79 \%$ of the employees responded that they didn't get any training on the software relevant to the work of their respective process.

Table 2: Perception of process owners and employees on layout design and software training

\begin{tabular}{|l|l|r|r|r|}
\hline & \multicolumn{1}{|c|}{ Questions } & Yes & No & Total \\
\hline 1 & $\begin{array}{l}\text { Is the layout of your office } \\
\text { arranged based on the flow of } \\
\text { work in the process? (n = 5 } \\
\text { processes) }\end{array}$ & 1 & 4 & 5 \\
\hline 2 & $\begin{array}{l}\text { Did you receive appropriate } \\
\text { software training to be able to } \\
\text { operate the identified the process } \\
\text { in which you are in? (n= } \\
\text { employees) }\end{array}$ & 3 & 37 & 40 \\
\hline
\end{tabular}

Source: Adopted from the survey conducted by the Civil Service Reform Office of the MCB, 2008

In addition, all processes of the Ministry didn't finish preparing new manuals and new forms until the end of June 2007. Automation requires the design of appropriate forms to capture relevant data. Even if it were possible to design new financial forms, the Ministry could not use the forms unless it gets permission from MOFED.

Horizontal integration: The BPR study had resulted with 
merging the procurement function with the finance function, to create a new end-to-end process. The Reengineering Team adopted the "one stop-shopping" technique to handle all other payment activities (per diem, transport allowance, payroll, etc.) that do not fall within the sequential flows of purchase-payment activities. Hence, the merging couldn't create the natural horizontal integration between the two functions because the "one stop-shopping" approach couldn't eliminate the boundaries between the merged finance and procurement sub processes.

The MIS solution: MIS is the use of computers to extract data from the database and to prepare performance reports that would allow management to make decisions. Though there is an MIS unit, its staff is not involved in any BPR study. The high level use of computers to enhance the capacity of management in monitoring and evaluating the performances of the programs, which is one of its mandates, was not included in the BPR studies of the Ministry.

Network design: Networking is the linking of the internal processes to facilitate communication, to share knowledge and information within the Ministry, and the linking of the activities of the Ministry with the activities of external stakeholders to enhance efficiency of transaction. The Ministry had physically connected offices at the head office level. But network design would be effective if the databases of processes were connected vertically and horizontally.

\section{The organization redesign solution}

Empowerment: Authority, responsibility and accountability are the three most important variables in organization design. Empowerment means allowing employees to have the decision making right over the work they perform and over the resources they use for the work the employees assigned. In the Ministry, there were attempts to empower process owners to decide on minor purchases. The decentralization of decision making right on minor purchasing had two advantages. First, it would allow process heads to make petty purchases without going to the routines of the procurement procedures. Second, it would have relieved the procurement process from making frequent minor 
purchases and would have allowed the procurement manager to have time to concentrate on major procurement issues. In addition, the Steering Committee had empowered each redesigned process of the Ministry to correspond independently with external stakeholders. Even if, the Ministry made the stamps ready, no process owner used them and the stamps have been in store for more than two years.

Layout design: An assessment was made as to what extent the arrangement of the position of employees is designed based on the flow of tasks. Table 3 indicates that only one of the five processes could linearly arrange the position of employees where as the others could not. The organization was trying to apply the linear workflow layout design method to all types of processes in the Ministry. However, one process is different from the other in the type of customer's request, frequency of customer arrival, the cycle times to convert the input into output, the type of equipment used in the work process, and the type of interface that a process makes with different stakeholders. During consultation, the writer has identified the following four types of processes in the Ministry of Capacity Building (refer to Table 3).

\section{Table 3: Types of processes and their characteristics:}

\begin{tabular}{|l|l|l|c|}
\hline No. & Process type & \multicolumn{1}{|c|}{ Characteristics } & $\begin{array}{c}\text { Exemplary } \\
\text { process from the } \\
\text { Ministry }\end{array}$ \\
\hline 1 & $\begin{array}{l}\text { Continuous } \\
\text { process }\end{array}$ & $\begin{array}{l}\text { Customer request is highly frequent, random } \\
\text { arrival of customer, service request immediate, } \\
\text { short cycle time }\end{array}$ & None \\
\hline 2 & $\begin{array}{l}\text { Batch } \\
\text { process }\end{array}$ & $\begin{array}{l}\text { Low frequency, tasks are accumulated for } \\
\text { some time before being processed, arrival is } \\
\text { known and activity can be scheduled, cycle } \\
\text { time is too long, usually between one year and } \\
\text { five years }\end{array}$ & $\begin{array}{c}\text { Planning, } \\
\text { monitoring and } \\
\text { evaluation process }\end{array}$ \\
\hline 3 & $\begin{array}{l}\text { A mix of } \\
\text { continuous } \\
\text { and batch } \\
\text { processing }\end{array}$ & $\begin{array}{l}\text { Low frequency, external and major internal } \\
\text { procurement requests can be accumulated for } \\
\text { processing; some internal requests can be } \\
\text { random and processed immediately. Cycle } \\
\text { time is between few days and one year. }\end{array}$ & $\begin{array}{c}\text { Procurement and } \\
\text { finance process }\end{array}$ \\
\hline $\begin{array}{l}\text { Project } \\
\text { process } \\
\text { (research and } \\
\text { consultancy) }\end{array}$ & $\begin{array}{l}\text { Low frequency, request arrival is random, time } \\
\text { interval between two requests can be very } \\
\text { long, cycle time is between three months to } \\
\text { one year, most of the activities of the process } \\
\text { are done at the place of the customer }\end{array}$ & $\begin{array}{c}\text { Civil service } \\
\text { Reform Program }\end{array}$ \\
\hline
\end{tabular}

Source: Compiled by the author 
Each type of process requires its own layout design. In the MCB, the mix of linear and batch layout design might be appropriate for procurement and finance process; whereas the batch processing layout design might be appropriate for planning, monitoring and evaluation process.

Job design: generalist vs. specialist: Job design is an important issue because it is part of organizing activity. Many processes reported that they were rotating employees among different tasks to create "generalist" workers. However, specialized jobs could be simple or complex. Complex specialized tasks can be performed at individual level, for example, an economist researcher, or at organization level; for example, the Ministry of Finance and Economic Development (specialized to handle the financial and economic matters of the government). Therefore, to create a generalist or a specialist, jobs need to be designed in view of the technology, the variety of tasks, the working condition, motivational aspect, and the complexity in which the jobs are to be performed. One important point that deserves mention is the report of the human resource unit on the problems of filling the vacant positions, delay of the approval of job grading and the new salary scale by the Federal Civil Service Agency. At this point, the Minister suggested that a central agency would administer the salary of the civil service to avoid any discrepancy between the payments of two employees doing similar jobs but working in different government agencies. This hinted that the organizing activities and the associated rewards are subject to be controlled by another agency independent of the agency undertaking the BPR.

\section{The procurement and finance process and financial regulation}

This process was identified as one of the core processes of the MCB. The effort made to change this process was the cause for initiating fundamental issues that would have had high impact of change at the national level. The first part discusses the performance of the process after BPR and the second part discusses the issue of breaking the rules and assumptions, which was the main point of discussion in many of the meetings. 
Performance of the procurement and finance process after $\boldsymbol{B P R}$ : The time sheet of the process is used to collect the data for 56 working days and to measure the actual work time and the average lead-time of five activities.

Table 4: Performance of sub processes of the procurement and finance process

\begin{tabular}{|l|c|c|c|c|}
\hline \multicolumn{1}{|c|}{ Main activities } & Frequency & $\begin{array}{c}\text { Average Effective } \\
\text { Time of work (in } \\
\text { days) }\end{array}$ & $\begin{array}{c}\text { Average Duration } \\
\text { (Lead time in days) }\end{array}$ & $\begin{array}{c}\text { Percent of } \\
\text { effective time } \\
\text { to the lead } \\
\text { time }\end{array}$ \\
\hline International purchase & 3 & NA & > one year & NA $^{2}$ \\
\hline Direct procurement & 14 & 1.76 & 28.47 & $6.18 \%$ \\
\hline $\begin{array}{l}\text { Payment request and } \\
\text { payment }\end{array}$ & 123 & 0.45 & 4.04 & $11.14 \%$ \\
\hline Settlement & 40 & 0.28 & 2.93 & $9.56 \%$ \\
\hline $\begin{array}{l}\text { Payroll preparation } \\
\text { and payment }\end{array}$ & 3 & 1.86 & NA & NA \\
\hline
\end{tabular}

Source: Summarized from procurement and finance process time sheet

Table 4 shows only $6.2 \%$ of direct procurement processing time, $11.1 \%$ of the payment time and $9.6 \%$ of the settlement time were the actual time employees spent in doing the tasks. A case in each activity was idle for more than $88 \%$ of the time. The cases were either on the way to the next step, or they were in the hands of employees/departments waiting to be processed. One can refer to Table 4 that international procurement had long delays, taking more than one year. According to the procurement and finance head, his process was obliged to rework the bid documents returned from the World Bank because of the poor quality in specification and procedures. Some cases of international procurement were cancelled because of the expiry of the usage of finance. In general, the results in Table 4 illustrate that there are a lot of rooms for further improvement in the performance of the procurement process.

${ }^{2}$ NA $=$ Not available 
"Breaking the rules and assumptions" and the procurement rules: The causes of a specific problem may be written or unwritten rules exercised in the organization. For example, delay in procurement may be a problem in a government organization. The shortest possible time for any procurement is to empower the concerned process to order the item/service directly from the supplier. However, the procurement rule requires any civil service organization to establish a procurement committee and to purchase through open bid. Open bid requires additional steps of advertising bid, giving ample time to the bidders to compete, evaluating the bid by committees and finally submitting recommendation to the management for decision. From the perspective of good governance, these steps are essential to enhance transparency in the system and to provide equal opportunity (fairness) to all suppliers who have stakes in government purchases. In addition, the assumption behind the rule of establishing a procurement committee could be to make economic purchase and to minimize corruption. However, in one of the meetings, it was mentioned that "collusion" could result at the time of preparing specifications, making technical evaluation, negotiation between the organization and the supplier, and receiving the items. However, the procurement committee was unrelated to any of these activities, and led to the conclusion that the existence of the procurement committee was not serving its purpose.

The MCB took two measures to break the assumptions behind the financial rules. The first is challenging the importance of procurement committee, and the second is using e-mail for minor purchases instead of collecting three price quotes. At this juncture, it is important to introduce two issues.

1. Though the effort of the Ministry to challenge the importance of the purchasing committee was fundamental, it didn't prepare the modality how government organizations can procure goods and services without compromising the control of finance, which is highly susceptible to embezzlement.

2. The decision to replace the manual collection of three price quotes for e-mail collection was a radical idea. The e-mail purchase might not only speed up the process but also significantly reduce transaction costs of procurement. 
However, the e-mail option could not be implemented due to lack of commitment on the part of the procurement and finance process team and lack of confidence on the system to provide security.

The involvements of the Federal Civil Service Agency, for job grading and salary scale, and MoFED in procurement and financial administration, suggests the existence of external constraints when undertaking BPR. External constraints are rules, regulations and procedures imposed by external systems that directly affect the internal operation of the system under study. For example, the procedures of the World Bank affect the operational steps when a government organization uses borrowed funds to procure goods and services. Hence, it was beyond the control of any consultant to break the assumptions of the World Bank that established the procedures of international procurement. Recognizing the existence of external constraint enables us to separate activities into controllable and uncontrollable activities. This in turn allows to focus on the controllable activities and to decide the interventions needed to break the assumptions and to reverse the internal rules.

\section{Change and resistance}

Whenever there is change, there is resistance. In the mid of June 2007, the consultant team surveyed the attitude of employees to assess their readiness to accept new changes. Out of 44 employees filled the questionnaire, $66 \%$ of them agreed that the civil service system need complete change where as $30 \%$ of them responded that the civil service system need partial change. This result concurs with the result obtained for Ethiopian Road Authority (Yetemgeta, 2007: 207). On the other hand, out of the 17 members of the reengineering team only $29 \%$ suggested that the civil service need complete change where as the remaining $71 \%$ suggested the need of partial change. Further investigation is needed why this difference in response to the same question occurred between the reengineering teams' members and the rest of employees in the MCB. Hence, the majority of civil servants believe in the necessity of change.

By observing the ambit of the meetings and obtaining information 
through informal discussion, the researcher has found that employees had mixed feelings towards the change. There were few die-hards that argue in favor of old systems, few managing the managers that suggest to make their boss happy, many inadvertent resistors that resist for fear of losing their jobs, many the wait and see group that feel indifference about the change, and the few compassionates that tried to protect their friends or subordinates.

The discussions on resistance lead to raise one important question. "Is it ethical to make the employee reengineer his process?" In Ethiopia, government agencies provide the major share of employment in the country. For example, in the year 2006, the total number of civil service employees was 498802 (FCSA, 2006) where as the total number of employees in the manufacturing sector and teachers in private school was 121470 (Statistical Office, 2005).

Phrases like "BPR" and "Result Based Performance Management" have become the sources of fear and insecurity for the large number of civil service employees. Phrases like "reengineering is not downsizing" could be used to calm employees. However, eliminating non-value adding activities, automating activities or rearranging activities lead to restructuring organizations followed by the reshuffling/retrenchment of employees unless the volume of work demands otherwise. How would someone in the reengineering team react if the result of BPR leads to eliminating his/her job? Are individuals willing to abandon their status and benefits easily for the sake of the change if horizontal integration leads to the combination of two or three functional processes into one? Are the technocrats willing to accept changes if the result of the BPR leads to the obsolescence of their knowledge? These and other questions need answer when introducing change in the civil service organizations in Ethiopia. Taking the Ethiopian current employment condition into account, it is rare to find someone to convince himself that his job is unimportant if the reengineering result leads to the elimination of his position. The major causes of resistance are fear of losing jobs, benefits and status; and the obsolescence of skills and knowledge. Hence, resistance of change could come from employees, the middle managers, the professional or the top 
management.

\section{The BPR experiences of other civil service organizations}

There are two important issues that need further discussion. The first is an issue related to the procurement and finance process of the MCB, for which the solution may not be found in the Ministry itself but in other ministries. The second is related to the assessment of the practice of implementing BPR in other civil service organizations.

\section{ICT situation in MoFED}

It is the Ministry of Finance and Economic Development (MoFED) that regulates the procurement and financial operations of all government organizations. Hence, assessing the status and trend of automation in MoFED helps us to consider a strategy that brings significant impact on the design of the procurement and finance processes of all civil service organizations. Interviewing the Coordinator of Public Finance Sector Works of MoFED draws the followings summaries of the status of financial information systems in MoFED.

1. Budget and Disbursement Information System (BIS): This system has been used to prepare budgets and record disbursements. Zonal offices receive financial data in hardcopy from Woreda offices, key in the data into the computer, and finally send soft copies to the regional bureaus, which compile the financial data and send again in soft copies to MoFED.

2. Integrated Budget Expenditure System (IBEX). EU sponsored this system. IBEX handles double accounting system, and processes receivables, payables and asset registration. Currently, this system is loaded at federal level. If fully implemented, the system helps to coordinate the financial activities of all sector offices at Woreda /Zone level.

3. Integrated Financial Management Information System (IFMIS): Currently, MoFED has invited consultants to design this advanced information system with approximate cost of 
\$40 million. The system will have integrated components of Procurement, Payroll, Fixed Asset, Human Resource, Debt Management, and Revenue (Taxation) Management systems. IFMIS, if implemented, allows MoFED to control the financial activities of all federal ministries and to transfer electronic money to the account of each government agency in the National Bank of Ethiopia (NBE). Besides, the different government agencies can use the system to electronically request budget release and electronically submit different periodic financial reports. However, discussion with the project manager hinted that IFMIS has been suspended until MoFED reengineers its processes.

From the above discussion, one can draw that most Woreda level finance offices are below automation (manually process financial data), all Zonal and regional Finance Offices use computer, without having a database, to transfer data in soft copy; and MoFED has reached the stage of networking the financial activities of all federal offices. The reader should note that reengineering the procurement and finance process in MoFED would have significant impact on changing the procurement and financial systems of all ministries/agencies rather than wasting time, effort and money in studying the procurement and finance processes of each ministry.

\section{Assessing implementation of BPR in other civil service organizations}

At this point it is essential to assess the implementation of BPR in other civil service organizations so as to have a general picture of its effect on the whole civil service. The writer used interview and observation to draw the information summarized in Table 5 and the discussion that follows. 
Table 5: Organizations that improved their performances as a result of BPR

\begin{tabular}{|c|c|c|c|c|}
\hline Organization & $\begin{array}{l}\text { Performances } \\
\text { improved }\end{array}$ & $\begin{array}{l}\text { BPR (BPI) } \\
\text { Effect on } \\
\text { manpower }\end{array}$ & $\begin{array}{l}\text { Application that } \\
\text { created most impact } \\
\text { on performance }\end{array}$ & $\begin{array}{l}\text { Means of data } \\
\text { collection }\end{array}$ \\
\hline $\begin{array}{l}\text { Addis Ababa } \\
\text { Transport } \\
\text { Office } \\
\end{array}$ & $\begin{array}{c}\text { Renewing driving } \\
\text { license from } 2 \text { hrs to } \\
45 \text { minutes } \\
\end{array}$ & NA & $\begin{array}{l}\text { IT (Database of } \\
\text { Vehicles) }\end{array}$ & Observation \\
\hline $\begin{array}{l}\text { Addis Ababa } \\
\text { branch CBE }\end{array}$ & $\begin{array}{c}\text { Withdrawing } \\
\text { money from the } \\
\text { bank, changed the } \\
\text { two steps to one } \\
\text { step }\end{array}$ & NA & $\begin{array}{l}\text { IT (Database of Bank } \\
\text { Clients) }\end{array}$ & $\begin{array}{l}\text { Observation } \\
\text { made as a } \\
\text { customer }\end{array}$ \\
\hline $\begin{array}{l}\text { Ethiopian } \\
\text { Customs and } \\
\text { Revenue } \\
\text { Authority }\end{array}$ & $\begin{array}{l}\text { The cycle time for } \\
\text { tax collection of } \\
\text { cargo import/export } \\
\text { goods has reduced } \\
\text { from } 45 \text { minutes to } \\
13 \text { minutes }\end{array}$ & $\begin{array}{c}\text { Floating of some } \\
600 \text { employees } \\
\text { out of } 3000 \\
\text { employees }\end{array}$ & $\begin{array}{l}\text { IT (Database of } \\
\text { Business } \\
\text { Community) }\end{array}$ & $\begin{array}{l}\text { Interviewing } \\
\text { and } \\
\text { Observation }\end{array}$ \\
\hline $\begin{array}{l}\text { Ministry of } \\
\text { Trade and } \\
\text { Investment } \\
\text { Office }\end{array}$ & $\begin{array}{l}\text { Cycle time of } \\
\text { registration and } \\
\text { licensing service } \\
\text { reduced from } 43 \\
\text { days to } 30 \text { minutes }\end{array}$ & $\begin{array}{l}\text { Manpower } \\
\text { reduced from } \\
120 \text { to } 90\end{array}$ & $\begin{array}{l}\text { IT (Database of } \\
\text { Investors) }\end{array}$ & $\begin{array}{l}\text { Interviewing } \\
\text { and observation }\end{array}$ \\
\hline $\begin{array}{l}\text { Ministry of } \\
\text { Agriculture } \\
\text { and Rural } \\
\text { Development } \\
\text { (MoARD) }\end{array}$ & $\begin{array}{l}\text { The BPI project } \\
\text { shortened the cycle } \\
\text { time of preparing } \\
\text { facilities for } \\
\text { fieldwork from ten } \\
\text { days to two hours. } \\
\text { The same is true for } \\
\text { settling accounts } \\
\text { after fieldwork. }\end{array}$ & $\begin{array}{l}\text { BPR has resulted } \\
\text { with reduction of } \\
300 \text { out of } 970 \\
\text { employees }\end{array}$ & $\begin{array}{l}\text { IT Automating } \\
\text { Finance and } \\
\text { Procurement function } \\
\text { of the Ministry }\end{array}$ & Interviewing \\
\hline
\end{tabular}

Source: Compiled by the author

As can be seen from Table 5, BPR or BPI has significantly reduced the cycle time of processes and the size of employees. The reduction in the size of employees has an indirect implication of cost saving. In addition, all of the above agencies, except MoARD, have database of their customers. The improvement in the performance of agencies can be attributed to the use of IT in processing customer's request.

Missed lessons from business process improvement: One thing to note from Table 5 is the business process improvement (BPI). Most civil service organizations started reengineering their processes in 2004. BPI is the name given to the reengineering practice before the civil service organizations were advised to reengineer the whole organization rather than a particular functional unit in 2006. Nevertheless, BPI had brought some 
breakthroughs in some civil service organizations. The writer interviewed the Civil Service Reform team of the Ministry of Foreign Affairs (MFA) about their achievements in their reengineering practice of BPI. The team responded that the result of BPI proposed to prepare suppliers list every three years, designed computerized suppliers and financial database, and introduced new standards and procedures to link the procurement request with the procurement plan of departments. In addition to the significant saving achieved in transaction cost, the design challenged the financial and procurement rules, procedures and regulations of MoFED that had been the discussion point in the MCB for almost three years.

Capacity of consultancy input: The Ethiopian Management Institute and the Ethiopian Civil Service College, the two agencies responsible for assigning BPR consultants, assigned 22 and 20 consultants respectively. Out of the 20 consultants assigned to consult different civil service organizations, more than $90 \%$ of them were having Masters Degree and above. However, only $20 \%$ of them have had management background, which is slightly related to BPR. The other $75 \%$ of them had other qualifications totally unrelated to BPR. According to Yetemgeta (2007: 204), $77 \%$ of the organizations he surveyed were not satisfied with the contribution of the assigned BPR consultants. This shows that the assigned consultants were not having the required capacity for reengineering a government agency. Preparing strategic plan, reengineering a process and implementing a result based performance management system need resources (e.g. time and finance), patience and commitment of management, and knowledge and skill of experts. Quality inputs lead to quality results. Mere commitment is not sufficient to bring radical change unless the commitment is supported with the appropriate knowledge, experience and profession. When a non-relevant professional leads a project, the project misses the technical leadership and its probability of failure is very high.

\section{Findings}

1. Even-if the mission of the MCB was mainly coordination of different programs and was not suitable to test BPR; the effort of implementing BPR in it was appreciated. In addition, 
fundamental issues such as questioning the importance of procurement committee and radical ideas such as connecting the Ministry with the suppliers through e-mail were highly discussed. The other point that deserves mention here is the commitment of the management team to bring change. The higher officials of the Ministry, including the Minister, were attending almost $90 \%$ of the Steering Committee meetings and they were giving the necessary supports and leadership. Above all, participants were free to speak their minds, even in the presence of the Minister. Eventually, however, final decisions rest with the Minister.

2. The need for knowledge in systems and IT area: The works of many scholars (Mihyar Hessen, 2007, Petter Fettke and Peter Loos, 2007, Hammer, 1993) on BPR suggest the importance of knowledge in database design and information systems (IS) at the time of reengineering processes. The Ministry didn't assign any IS specialist in any of its reengineering teams. Hence, the non-consideration of automation at the time of reengineering has made all the redesigned process to be incomplete and non-exhaustive.

3. BPR has become an end by itself rather than being a means: The meetings were forums of hot discussions in an effort to prove the aptness of one's interpretation of BPR, according to the written books, without focusing on the benefits or the outcome of the BPR. Hence, this experience has shown that BPR was increasingly being regarded more as an end than a means. The inability to do a thorough work at the beginning of the study has also led the Ministry to take more than two years to clarify the ambiguities and to rectify the defects in the design.

4. Fitting civil service organizations into Vanktraman's model: All the support and core process of MCB have not created databases to improve the efficiency of their internal activities. This indicates that the Ministry is below the level of automation. On the other hand, Customs and Revenue Authority, the saving department of the Addis Ababa branch Commercial Bank of Ethiopia., the Addis Ababa Transport 
Office (Tilaye, 1999: 24), Ministry of Industry have automated their core internal processes even some have reached the level of integrating horizontal activities. Probably, MoFED, may reach the level of network redesign when it uses the network to control the financial activities of federal agencies.

5. "One size does not fit all": All processes can have similar characteristics such as inputs, process and outputs. Many government agencies were having problems of identifying their customers and the type of services they deliver. However, no government organization is a "black hole" system that takes in only inputs without producing any output. Each government agency has its own specific mission to undertake. Some agencies, like National Bank of Ethiopia and Ministry of Justice, have the missions of regulating the operation of other agencies or business organizations. Some agencies, like Revenue and Customs Office have the mission of collecting taxes from different groups of people/entities. Hence, different approach would be required to reengineer the government agencies with different missions.

6. Inability to tap knowledge obtained from the experiences of designing functional processes: Had the study results of the BPI were tapped and used during BPR, there would have been high cost saving and would have brought significant changes in the procurement processes of all government agencies.

7. "Gravity" towards the center: It was discussed elsewhere in this paper that many process owners of the MCB were avoiding minor decision-making rights. This indicates that managers in the civil service want to make decisions within the boundaries of the existing government rules and procedures so as to be safe from risks of accountability and any responsibilities for their action. This result validates the established theories about the relationship between the principal and the agent, and the relationship between risk and reward. The suggestion of the Minister on the central administration of salary scale and the continuing practice of MOFED in controlling financial and procurement activities of 
different government agencies indicate that the government is not ready to cede central control for the foreseeable future to come.

8. Duplication of effort: Each government agency was redesigning its procurement and finance process. However, MoFED is the responsible agent to control the procurement and financial administration of any civil service organization. In the near future, the operations of civil service organizations cannot be free from respecting the rules, regulations, procedures and forms of MoFED. Hence, reengineering the procurement and financial process in MOFED, and replicating it later to other civil service organizations would have saved a lot of effort and cost of reengineering.

\section{Conclusion and Recommendations}

It was discussed in the literature that BPR is more of a science than of an art. The scientific technique required for reengineering business processes does not exclude the importance of the art needed for implementing the change. As a tool of organizational change, BPR needs the ideological support from both managers and political leaders. This was why Hammer and Stanton (1994: 34-37) emphasized on the importance of the involvement and commitment of the leadership at the time of reengineering a process. Hence, the commitment shown by the leadership to change the civil service was highly appreciated and should be encouraged to keep up with the existing spirit of change.

In conclusion, it is essential to consider the following points so as to effectively apply BPR to improve service delivery in the Ethiopian civil service.

1. To recognize the differences between the characteristics of government organizations and the characteristics of profit making corporations: It is discussed in the case that the experience in civil service organizations so far seems to copy the "As Is" BPR of corporations designed in high-tech and high human capacity environment. The operational nature of civil service organizations, the principles of good governance, the political ideology of the ruling party and the personal interest of a particular public sector manager are some of the 
main factors that negatively or positively influence the process design of a government organization. A manager of corporation has the power to make any decision whenever he/she deems it necessary. In contrast a manager of a civil service organization relies on rules, procedures and regulations of the central regulatory agencies to make recruitment and procurement decisions.

2. To recognize that the use of ICT is vital for successful implementation of BPR: The finding in this paper indicates that BPR significantly improved the performance of organizations whose processes are amenable for application of ICT. In the context of Ethiopia, ICT seems very crucial in reengineering business processes. For example, it is the transport technology that shortened the one-month foot trip to a few hours or days. Hence, excluding the use of ICT from the equation of BPR results with the traditional organizing activity. For a developing country, automation may not necessarily be a precondition for reengineering the business process because of "the late comer advantage". Hence, an organization in a developing country can reengineer its process (Leenden, 1989: 119), but the result of BPR should indicate the extent of automation for the new system. Therefore, it is vital to use Venkatrman's model to determine at which level of IT transformation that an organization is found so as to use the appropriate strategy of reengineering its processes.

3. To recognize that the high human resource capacity is determinant for success of BPR: this can be viewed from two angles. The first is from the perspective of BPR consultants, and the second from the perspective of government employees.

a. From the perspective of the system consultants: BPR is mainly a science and to a less extent an art. As a science, BPR has its own methodologies, techniques and approaches that can be transferred through series of training exercises. As an art, BPR requires creativity and leadership skills for its success. Hence, it is advisable to train consultants in courses like organization design and 
development, introduction to public administration, systems analysis and design, operations management, project management, strategic management and finally to do a project assignment.

b. From the perspective of employees: It is the people that make the system of any organization run properly. A super professional may design a super system. However, the new system may die at the inception phase unless the users are capable and are willing to use it. The government is the major employer in the country and it is discussed elsewhere that BPR has a negative effect on the size of employees. Besides, the Ethiopian private sector does not have the capacity to accommodate the redundant work force released from the civil service. Even if most government employees believe in the change, they may resist the change if they feel insecure in their jobs. Therefore, the government needs to pay attention to this concern of employees in parallel with the organizational change work. In addition, individuals join organizations to promote different kinds of personal interests such as status, power, job security, economic, etc. Besides, the operations of civil service organizations are highly influenced by the political condition prevailing at a particular time. At the time of reengineering, members in the reengineering teams may articulate their different interests that may in turn lead to conflicts. Hence, to use consultants or experts outside the organization as facilitators of BPR may be advisable to minimize the conflicts within the organization.

4. To use the strategy of adapting more than adopting: currently the belief seems that it is possible to implement a system by copying the techniques from the books written in high tech countries. It is true that Hammer used his computer knowledge and experience as a background to contribute new techniques of designing organization from the perspective of profit making corporate. Social science theories develop in their own context. A social science theory developed for a particular situation may not work in another situation. Hence, 
5. To use the strategy of soft system approach: It is vital to recognize processes vary from one government organization to another in terms of functions and behaviors (refer to the "one size does not fit all). Some organizations have continuous processes, for example, all the Municipalities of the Sub Cities of Addis Ababa. Some organizations have intermittent processes, for example, the Ministry of Capacity Building (MCB). Even processes within an organization perform different functions and demonstrate different behaviors (refer to table 3). Hence, it is advisable to classify government organizations based on their mission and to apply BPR on those organizations/processes with continuous inflow of customer requests in parallel with devising a strategy on how to reengineer the organizations for which the lead time is too long and the inflow of requests are few.

6. To recognize that the invention of systems leads to preparing guidelines but not the reverse: The case indicated that the staff of the MCB used Hammer's book as guideline and manual to implement BPR. This practice is the same for all civil service organizations. Until now the government has invested a lot of resources to obtain new civil service systems by training employees and by preparing manuals and guidelines. Guidelines and procedures are glues that attach the different components of a system to be cohesive and to operate in unison. However, it is important to note that it is the creation of systems that leads to the creation of guidelines but not vice versa. Hence, establishing a strong research team becomes the order of the day to use systematic approach for creating and strengthening new civil service systems in Ethiopia. 


\section{References}

Borins, S. (undated). New public management: North American style. In McLaughin etal, ed. 2000. New public management: current trends and future prospects. UK: Routledge Publishers: Taylor and Francis Group.

Burns, B., 2000. Managing change: a strategic approach to organisational dynamics. $3^{\text {rd }}$ ed. Harlow: Pearson Education Limited.

Central Statistical Agency, 2006. Statistical Abstract. Addis Ababa, Ethiopia.

Davies, C. A, Demb, R. E, 1979. Organisation for program management. John Wiley and Sons.

Federal Civil Service Agency (FCSA), 2006. Personnel Statistics. Addis Ababa, Ethiopia.

Fettke, P, Loss, P. 2007. Framework and meta-model for specifying business components. Business Process Management Journal, Vol. 13, No. 5: 628 - 643.

Haag, S, Cummings, M, and Dawkins, J. 1998. Management information systems for the information age. Irwin: McGraw-Hill.

Hammer, M, Champy, J. 1993. Reengineering the corporation: a manifesto for business revolution. London: Nicholas Brafley Publishing.

Hammer, M, Stanton, S. A. 1995. The Reengineering Revolution: the Handbook. Haiper Collins Publisher.

Hesson, M., 2007. Business process reengineering in the public sector: a naturalization and residency case study. Business Process Management Journal, Vol. 13, No. 5: 707- 727.

Leenders, F. 1989. Purchasing \& materials management. $9^{\text {th }}$ ed. Richard D. Irwin Inc. 
Laudon, K. C, Laudon, J. P. 1999. Management information systems: organization and technology. $4^{\text {th }}$ ed. New Delhi: Prentice Hall of India.

Linden, R. M. 1994. Seamless government: a practical guide to re-engineer in the public sector. San Francisco: JosseyBass Publishers.

Ministry of Capacity Building (MCB), 2006. Business process reengineering study, Final report, Addis Ababa: MCB.

Monks, J.G. 1987. Operations management: theory and problems. $3^{\text {rd }}$ ed. McGraw-Hill.

Nault, B. R. 1998. Information technology and organisation design: locating decision and information. Management Science, Vol. 44, No. 10: 1321-1335.

Proclamation on Reorganisation of the Executive Organs of the FDRE 2001. (Negarit Gazette, Proclamation No. 256/2001), Addis Ababa, Ethiopia.

Proclamation on Definition of Powers and Duties of the Executive Organs of the FDRE 2005. (Negarit Gazette Proclamation No. 471/2005), Addis Ababa, Ethiopia.

Stahl, O. G. 1962. Public personnel administration. $5^{\text {th }}$ ed. Harper \& Row Publishers.

Terry, G. R, Franklin, S. G. 1991. Principles of management. $8^{\text {th }}$ ed. Delhi:.All India Traveler Booksellers.

Tesfaye Debela. 2009. The role of IT in enhancing the administrative capacity of the civil service: lessons from the USA. Journal of Business and Administrative Studies, Vol. 1 No. 1: 21-47.

Tilaye Kassahun. 2007. Civil service reform in Ethiopia: achievements, problems and possible solutions. In: ECSC (Ethiopian Civil Service College), the Proceedings of the First National Conference on the Achievements, 
Challenges and Prospects of the Ethiopian Civil Service Reform Program Implementation in Ethiopia. Addis Ababa, Ethiopia May 31-June 1 2007. ECSC: Addis Ababa.

Venkatraman, N. 1994. IT enabled transformation: from automation to business scope redefinition. Sloan Management Review, 35 (2).

Yetimgeta Asrat. 2007. Approaches to change management in the Ethiopian civil service: emphasis on Ethiopian Roads Authority. In: ECSC (Ethiopian Civil Service College), the Proceedings of the First National Conference on the Achievements, Challenges and Prospects of the Ethiopian Civil Service Reform Program Implementation in Ethiopia. Addis Ababa, Ethiopia May 31-June 12007. ECSC: Addis Ababa.

\section{Acknowledgement:}

I would like to thank the Ministry of Capacity Building for allowing me to work as one of its members. I would like also to thank W/o Almenesh Worku, Head of Civil Service Reform Office of the MCB, Ato Mussa Mohammed, Coordinator of Public Finance Sector Works in MoFED, Ato Asmare Emire and all those who have sacrificed their time to make this paper possible. 